\title{
BULANIK MANTIK MODELLEMESİ İLE TAŞINMAZ DEĞERLEMEYE FARKLI BİR BAKIŞ
}

\author{
Yeșim ESEN ${ }^{*}$, Hanifi TOKGÖZ ${ }^{2}$
}

1İzmir Çiğli Belediyesi, İmar ve Șehircilik Müdürlüğü, İzmir, Türkiye

${ }^{2}$ Gazi Üniversitesi, Teknoloji Fakültesi, İnşaat Mühendisliği Bölümü, Ankara, Türkiye

\begin{tabular}{ll}
\hline Anahtar Kelimeler & Öz \\
\hline Taşınmaz Değerleme, & Bu çalışmada taşınmaz değerlemede bulanık mantık modellemesinin \\
Bulanık Mantık, & uygulanabilirliğinin ve hazırlanan veri setindeki değişkenlerin azaltılmasının \\
Çoklu Regresyon, & yöntem üzerindeki etkilerinin araştırılması amaçlanmaktadır. Araştırma sahası \\
Stepwise Regresyonu. & olarak İzmir ili muhtelif ilçelerinde 120 tane bağımsız bölümün değerleme raporu \\
& kullanılmıştır. Değişkenler seçilirken, zaman ve ekonomik açıdan kazanım \\
& sağlanması, bürokratikişlemlerin en aza indirilmesi göz önünde bulundurulmuştur. \\
& Bu kapsamda değişkenlere nitelik azaltma işlemi uygulanmış olup, en az değişken \\
& ile istatistiksel olarak en başarılı veri setine ulaşılmıştır. Yapılan istatistiksel \\
& analizler taşınmaz değerlemede, bulanık mantık modellemesinin daha hızlı ve \\
& düşük hata payı ile tahminde bulunduğunu göstermektedir. Çalışmanın bulgularıbir \\
& bütün olarak değerlendirildiğinde; nitelik azaltma işlemi kullanılarak, bulanık \\
& mantık modellemesinin taşınmaz değerlemede alternatif bir yöntem olarak \\
& kullanılabileceği düşünülmektedir.
\end{tabular}

\section{A DIFFERENT PERSPECTIVE TO REAL ESTATE VALUATION WITH FUZZY LOGIC MODELING}

\section{Keywords \\ Real Estate Valuation, \\ Fuzzy Logic, \\ Multiple Regression, \\ Stepwise Regression.}

\begin{abstract}
The aim of the study is to investigate the feasibility of fuzzy logic modeling in real estate valuation and the effects of reducing the variables in the prepared data set. The data set is consisted of 120 valuation reports prepared for buildings located in various districts of Izmir. In the selection of variables for the model, saving time and economic sources, minimizing bureaucratic procedures are taken in consideration. In this context, a quality reduction process was applied to the variables and statistically the most accurate model with minimum variables was tested. Statistical analyzes showed that, fuzzy logic modeling predicts the value of real estates faster and with lower margin of error. The results of the study indicated that quality reduction with fuzzy logic modeling can be an alternative method in real estate valuation processes.
\end{abstract}

\section{Alıntı / Cite}

Esen Y., Tokgoz, H., (2021). Bulanık Mantık Modellemesi ile Taşınmaz Değerlemeye Farklı Bir Bakış, Mühendislik Bilimleri ve Tasarım Dergisi, 9(4), 1155-1165.

Yazar Kimliği / Author ID (ORCID Number)

Y. Esen, 0000-0001-9154-3235

H. Tokgöz, 0000-0002-4826-7973

\begin{tabular}{|l|l}
\hline Makale Süreci / Article Process \\
\hline Başvuru Tarihi / Submission Date & 08.02 .2021 \\
Revizyon Tarihi / Revision Date & 05.07 .2021 \\
Kabul Tarihi / Accepted Date & 26.07 .2021 \\
Yayım Tarihi / Published Date & 20.12 .2021 \\
\hline
\end{tabular}

\section{Giriş (Introduction)}

Taşınmaz değerleme gerek genel ekonomik dinamikler gerekse kentsel dönüşüm ve kamulaştırma süreçleri bakımından önem taşıyan konulardan biridir. Bu çok boyutlu kavram, farklı değerleme yöntemlerinden değerleme sürecinin aşamalarına, sürece bilgi teknolojilerinin entegrasyonundan değerleme uzmanlarının rolüne kadar geniş bir yelpaze de çalışılmaktadır (Köktürk, 2009). Değerleme çalışmaları yapılırken kullanılan farklı yöntemler, aynı

\footnotetext{
* ilgili yazar / Corresponding author: yesimttoprak@gmail.com, +90-232-520-6000/1651
} 
taşınmaza ait farklı değer sonuçlarını karşımıza çıkarabilmektedir. Her kurum kendi menfaatini düşünerek kendine has yöntemler kullanıp ve yine taşınmazın kendilerini ilgilendiren özelliklerini ön plana çıkartarak değerleme yapmaktadır (Eren vd., 1999; Nişancı, 2005). Taşınmaz değerlemesinde kullanılan değişkenler ve bu değişkenlerin hangisinin daha önemli olduğu bilinmediğinden bilimsel bir yöntemin kullanılması ile taşınmazların gerçek değeri daha isabetli belirlenebilir. Tașınmaz değerleme Almanya, Hollanda, İsviçre, İngiltere gibi ülkelerde bir sisteme oturtulmuş olsa da ülkemizde bu konuda bir takım yasal boşlukların bulunması bu süreci zorlaştırmaktadır (Yomralıoğlu vd. 2011). Bu konuda ülkemizde değişkenlere ilişkin mevzuatta birçok kanun, tüzük, yönetmelik, genelgeler ve tebliğler bulunmaktadır. Bazı mevzuatlardaki uygulama için taşınmaz türlerine göre değeri etkileyen değişkenler belirlenmemiş, bazılarında tür ayırımı dikkate alınmamıștır (Yalpır ve Bünyan Ünel, 2016). Bu durum, ülkemizde de taşınmaz değerleme konusunun diğer ülkelerdeki gibi somut bir hale getirilmesi için bazı çalışmaların başlamasını sağlamıştır (Tabar ve Şişman, 2020). Bu çalışmalarla ilgili literatürde alternatif yöntemler öne sürülmektedir. Öne sürülen bu metotlar içerisinde günümüz teknolojisinin varmış olduğu son nokta; makinelere insan davranışlarını anlayabilen ve uygulayabilen özelliklerin kazandırılması (Elmas, 2011) olan yapay zekadır. Yapay zekâ üzerinde en çok araştırma yapılan konu yapay sinir ağlarıdır. Bulanık mantık ile ilgili çalışmalar ise son yıllarda hız kazanmıştır.

Araştırmanın, çalışma alanı toplam 30 ilçenin bulunduğu İzmir ilidir. Bu ilçelerden 16' sından alınan 120 adet bağımsız bölüme ait taşınmazın gerçek değeri ve bu taşınmazlara ait değerleme raporlarından 9 adet değişken verisi toplanmıştır. Kullanılan veriler 2010 ile 2013 yılları arasındaki zaman dilimlerine aittir. Tespit edilen gerçek taşınmaz değerleme bedelleri 55 000,00 TL ile 280 000,00 TL aralığında değişmektedir.

Oluşturulan veri seti, 9 adet bağımsız değişken (girdi) (Ulaşım, daire alanı, cephe durumu, otopark durumu, binanın yaşı, asansör, manzara, gelir seviyesi ve yapı kalitesi) ve 1 adet bağımlı değişken (çıktı)( bağımsız bölümün satış değeri) olarak hazırlanmıştır. Veri setine önce bulanık mantık uygulanmış ve sonuçlar çoklu regresyon analizi ile karşılaştırılmıştır. Zaman ve ekonomik açıdan kazanım sağlanması, bürokratik işlemlerin en aza indirilmesi göz önünde bulundurulduğundan veri setine nitelik azaltma işlemi uygulanmıştır. Nitelik azaltma işlemi hem stepwise regresyonu hem de bulanık mantık ile yapılmıș olup her iki yöntemde de aynı 3 değișken anlam kazanmıștır. Bu 3 bağımsız değişken ve 1 adet bağımlı değişken veri setine bulanık mantık uygulanmış ve çoklu regresyon analizi ile karşılaştırılmıştır. Çalışma sonucunda nitelik azaltma işlemi kullanılarak, bulanık mantık modellemesinin taşınmaz değerlemede alternatif bir yöntem olarak kullanılabileceği düşünülmektedir.

\section{Literatür taraması (Literature Review)}

Yapay zekâ ve taşınmaz değerleme ile ilgili literatürde ilk kez Borst (1991) tarafından Yapay Sinir Ağları kullanılarak taşınmaz değerleme çalışmalarına başlanmıştır. Worzala vd. (1995) güncel satış verilerini kullanarak yapay sinir ağı modelini, çoklu regresyon modeli ile kıyaslayarak, yapay sinir ağlarının geliştirilerek taşınmaz değerlemede kullanılabileceğini ifade etmişlerdir. Rossini (1997) makalesinde; yapay sinir ağlarının geliştirilmesiyle taşınmaz değerlemesinde daha geçerli bir analitik araç haline getirilebileceğine değinmiştir. Cechin vd. (2000) ve Khalafallah (2008) yapay sinir ağlarının taşınmaz değerleme ve kira verilerini başarılı biçimde modellendirmiş olduğunu teyit etmişlerdir. Kim vd. (2004) çalışmalarında, inşaat maliyetlerinin, vaka bazlı akıl yürütme ve yapay sinir ağları modelleri ile tahmin edilebileceğini ifade etmişlerdir. Esperanza ve Gallego (2004) çalışmalarında yapay sinir ağlarının en iyi çok katmanlı ileri beslemeli ağlarda çalıştığını tespit etmişlerdir. Budzyński ve Wilkowski (2006), çalışmalarında yapay sinir ağlarının hem taşınmaz değerlerinin belirlenmesinde kullanılabilir hem de taşınmaz fiyatlarını yüksek derecede etkileyen taşınmaz özelliklerinin seçimin de kullanılabilir olduğunu göstermişlerdir. Zurada vd. (2006) çalışmalarının sonucunda, taşınmaz değerlemede "bulanık" verilerin yer alıyor olmasının satış fiyatlarını tespit etme yeteneğine katkı sağlayabileceğini ileri sürmüşlerdir. Özkan vd (2007) çalışmalarında birçok veriyi regresyon ve yapay sinir ağları yöntemleri ile birlikte kullanarak analiz etmişler ve taşınmaz değerlemede hızlı ve güvenilir sonuçlar elde etmişlerdir. Garcı'a vd. (2008) bu çalışmalarında yapay sinir ağı ve coğrafi bilgi sistemi kombinasyonunun taşınmaz değerlemede çok yararlı ve güçlü bir araç olduğunu kanıtlamışlardır.

Nas Bulut (2011) tez çalışmasında taşınmazlara ait bilgileri kullanarak yapay sinir ağları ve destek vektör makinesi aracılığıyla bir yöntem geliştirmiştir. Dikmen ve Saraç (2012), bu çalışmalarında taşınmaz değerlerinin tahmini için taşınmazın hizmet seviyesi ve muhitin gelir seviyesini dikkate alan yapay sinir ağlarına dayalı bir model geliştirmişlerdir. Saraç (2012) tez çalışmasında taşınmaz değerlemesinde yapay sinir ağlarını kullanarak bir model geliştirmiştir. Çakır ve Sesli (2013) makalelerinde taşınmaz değerleme alanındaki yetkin kişilere bir anket çalışması yapmışlar ve güvenilirlik analizi, normallik varsayımı, varyans analizi kullanarak arsa vasıflı bir taşınmazın değerini belirlerken 15 değişken ile çalışılabileceğini belirlemişlerdir. Derinpınar ve Aydınoğlu (2015) çalışmalarında, nominal değerleme faktörleri ve bulanık mantık yöntemi kullanarak Coğrafi Bilgi Sistemlerinin taşınmaz değerlemede uygulanabilirliğini belirlemişlerdir. 
Bostancı vd. (2017) çalışmalarında bulanık bir değerlendirme gerçekleştirip, Coğrafi Bilgi Sistemi Destekli karşılaştırılabilir konut memnuniyet haritası oluşturmuşlardır. Demirel vd. (2018) çalışmalarında çok ölçütlü karar verme yöntemlerinden biri olan Analitik Hiyerarşi Prosesi ile dairelerin değerlemesini yapmışlardır. Erdem (2017) makalesinde taşınmaz değerleme konusundaki 2010-2017 yılları arasında yapılan yüksek lisans ve doktora tezlerini içerik açısından irdelenmiș ve bulanık mantık yöntemi kullanılarak yapılan taşınmaz değerleme çalışmalarının sayısının giderek arttığını bildirmiştir. Işıklı (2019) makalesinde Coğrafi Bilgi Sistemi kullanarak yapılan taşınmaz değerleme sonuçlarının yüksek doğrulukla belirlendiğini bir örnek üzerinde açıklamış ve Sermaye Piyasası Kurulu tarafından, değerleme için toplanan verilerin depolanması ve ihtiyaç duyulduğunda paylaşılması durumunda taşınmaz değerleme hesaplarının daha hızlı olacağını öne sürmüştür. Hong vd. (2020) ve Canaz Sevgen ve Aliefendioğlu Tanrıvermiş (2020) makalelerinde Rastgele Orman Regresyon yönteminin taşınmaz değerlemesinde kullanılabilirliğini göstermişlerdir.

Literatüre bakıldığında, çok sayıda değişken kullanılarak hazırlanan veri setleriyle veya anket çalışmaları uygulanarak yapılan çalışmalara rastlanmıştır. Ancak zamandan ve ekonomik açıdan kazanım sağlanabilmesi, bürokratik ișlemlerin azaltılması için, en az değișkene sahip veri setleri ile anlamlı sonuca ulașılması konusunda yapılan çalışmaların oldukça sınırlı olduğu saptanmıştır. Bu araştırmada, yapılan diğer çalışmalardan farklı olarak, veri setine nitelik azaltma uygulanıp en az değişken kullanılarak, bulanık mantık modellemesiyle taşınmaz değerleme çalışmaları için yeni bir yaklaşım önerilmektedir.

\section{Materyal ve Yöntem (Material and Method)}

\subsection{Teorik Yöntem (Theoretical Method)}

Taşınmaz değerlemesinde kullanılan yöntemleri geleneksel, istatistiksel ve modern yöntem olarak üç ana başlık altında toplayabiliriz. Geleneksel yöntem olarak kullanılan piyasa yaklaşımları ya da diğer bir değişle karşılaştırmalı satış analizi günümüzde en çok kullanılan yöntemdir. Ancak bürokratik iş ve işlem basamaklarının çok olması, yapı maliyetlerinin değişik alanlar için sonuca gitmede yetersiz kalması, benzer özellikli taşınmaz bulma zorluğu gibi sıkça karşılaşılan sorunlar çok fazladır (Yalpır, 2007). Bunları en aza indirmenin yollarını ararken karşımıza modern yöntemler çlkmaktadır. Özellikle son zamanlarda bu modern yöntemlerin kullanılmasının değerleme çalışmalarına katkılarının yadsınamaz derecede arttığı görülmektedir. Sadece sayısal veriler olarak değil sözel ve görsel olarak da analizlere veri giriși yapılabilmektedir. Örneğin uydu görüntüleri, GPS ve lazer taramaları ile değerleme yapılabildiği gibi, insan beyninin düşünme şeklinin bilgisayara aktarımı (Elmas, 2011) ile de yapılabilmektedir. Ayrıca bu yöntemlerin istatistiksel analizlerle de kullanılabilirliği ispatlanmaktadır. Taşınmaz değerlemesinde istatistiksel verilerin kullanılması, faydalanıcılara subjektif bulgular yerine, objektif olarak sonuçlar verebilme imkanı sağlamaktadır (Nişancl, 2005). Çalışmada hazırlanan veri setinin değerlendirilmesi amacıyla SPSS 23.0 paket programında, çoklu regresyon ve stepwise regresyon analizi ile Matlab programında bulanık mantık modellemesi kullanılmıştır. Yapılan uygulama süreci aşağıda Şekil. 1' de verildiği gibi özetlenmektedir.

\begin{tabular}{|l|}
\hline Problemin tanımlanması \\
\hline Verilerin toplanması \\
\hline Verilere nitelik azaltma uygulanması \\
\hline Sistem için uygun üyelik fonksiyonunun seçilmesi \\
\hline Verilerin bulanıklaştırılıp tahmin sonuçlarının elde edilmesi \\
\hline Tahmin sonuçlarının gerçek değer olan satış değeri ile karşılaştırılması \\
\hline Sonuç \\
\hline Şekil 1.Modelin oluşturulmasındaki işlemler (Process of model development) \\
\hline
\end{tabular}

\subsection{1. Çoklu Regresyon (Multiple Regression)}

Çoklu regresyon modelinde, etkileyen değişkenlere açıklayıcı (bağımsız değişken), etkilenen değişkene de açıklanan değişken (bağımlı değişken) adı verilir. Y bağımlı değişken; $x_{1}, x_{2}, \ldots, x_{n}$ bağımsız değişkenler olmak üzere değişkenler arasındaki sebep sonuç ilişkisini matematiksel bir model olarak ortaya koyar (Es vd., 2014). Çoklu regresyon modelinin matematiksel gösterimi ise aşağıda Eşitlik 1'deki gibidir. 


$$
Y=b_{0}+b_{1} X_{1}+b_{2} X_{2}+\cdots+b_{n} X_{n}
$$

\subsubsection{Stepwise Regresyonu (Stepwise Regression)}

Stepwise Regresyonu, değişkenlerin regresyon denklemine belirli bir istatistiksel ölçüte göre sırayla eklendiği ya da sırayla seçildiği regresyon modelidir. Hangi değişkenlerin hangi sırayla modele gireceğine matematiksel bir kritere bakarak karar verilir. Eklenen ya da çıkarılan bağımsız değişkenlerin bağımlı değişken üzerinde anlamlılığına göre son modele karar verilir.

Üç çeşit Stepwise seçim yöntemi bulunmaktadır. Bunlardan ilki ileriye doğru seçim yöntemidir. Her defasında bir bağımsız değişken ilave edilerek en uygun regresyon modelinin bulunmasını sağlar. İkincisi geriye doğru seçim yöntemidir. Bu modele tüm bağımsız değişkenler ile başlanmaktadır. Üçüncü ve son seçim yöntemi olan adımsal seçim yönteminde ise hem ileriye doğru seçim yöntemi hem de geriye doğru seçim yöntemi aynı anda kullanılmaktadır (Kayaalp vd., 2015). Çalıșmada söz konusu regresyon modelinin kullanılmasının ana nedeni bağımsız değişkenin ya da değişkenlerin hangisinin regresyon modelini anlamlandıracağını saptamaktır.

\subsubsection{Bulanık Mantık (Fuzzy Logic)}

Bulanık mantık her gün kullandığımız ve davranışlarımızı yorumladığımız yapıya ulaşmamızı sağlayan sadece (1) ve (0) mantığı içermeyen, günlük yaşantımızda kullandığımız daha esnek bir yaklaşımdır (Şen 2009; Kuzugüdenli 2018; Koçak ve Yiğit 2020). Bulanık mantığın uygulama alanları çok geniştir. Sağladığı en büyük fayda ise insana özgü tecrübe ile öğrenme olayının kolayca modellenebilmesi ve belirsiz kavramların bile matematiksel olarak ifade edilebilmesine olanak tanımasıdır (Özgür ve Kara, 2020). Bulanık mantık tabanlı bir sistem Şekil 2' de görüldüğü gibi; giriş, bulanıklaştırma, kural tabanlı çıkarım, durulaştırma ve çıkış bölümlerinden meydana gelmektedir (Kuzugüdenli 2018; Jang vd. 1996; Anand ve Tyagi 2012; Güner ve Çomak 2014; Yalpır 2007).

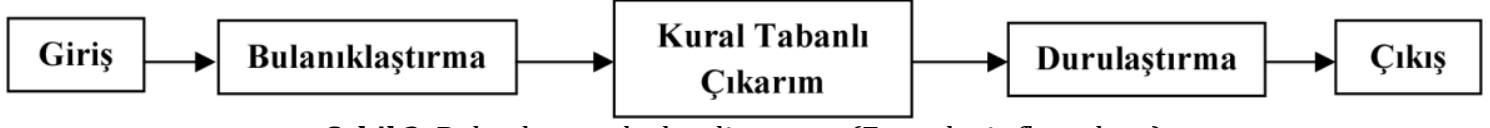

Şekil 2. Bulanık mantık akış diyagramı (Fuzzy logic flow chart)

Giriş, bağımlı ve bağımsız değişkenleri içerir. Bu değişkenlere karşılık gelen üyelik fonksiyonlarının seçilip, çalıştırılarak bir sonraki basamak olan bulanıklaştırma gerçekleştirilir. Bulanıklaştırılmış değișkenler, kural tabanlı çıkarım basamağındaki her bir kuralı, bir giriş değișkeni, çıkış değişkeniyle bağlamış olur. Tüm kuralların birlikte kullanılmasıyla sistem modelinin tamamını ifade eden bir kural tabanı oluşturulur. Durulaştırmada ise oluşturulan bu kurallar bulanık ifadelerin, sayısal ifadelere dönüștürülerek, bulanık mantığın model için oluşturduğu sonucu yani çıkışı oluşturur. Çalışmamızda bulanık mantık modellemesinde üyelik fonksiyonu olarak literatürde yaygın olarak kullanılan üçgen üyelik fonksiyonu kullanılmıştır. Üçgen üyelik fonksiyonu Şekil 3'de gösterildiği gibi bașlangıç $\left(0, \mathrm{a}_{1}\right)$, tepe $\left(\mathrm{a}_{1}, \mathrm{a}_{2}\right)$ ve bitiș noktaları $\left(\mathrm{a}_{2}, \mathrm{a}_{3}\right)$ ile tanımlanmıștır.

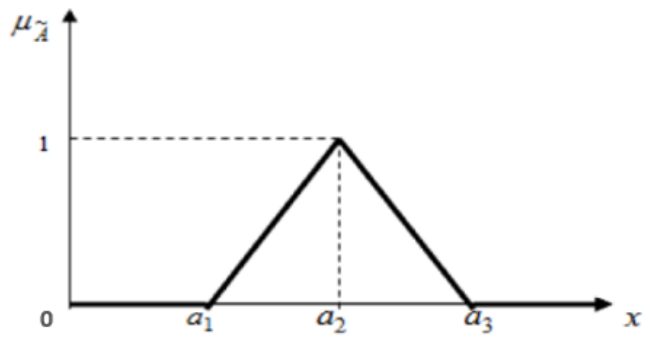

Şekil 3.Üçgen üyelik fonksiyonu (Triangle membership function)

Üçgensel üyelik fonksiyonunun matematiksel gösterimi ise aşağıda Eşitlik 2'de gibidir.

$$
\mu_{A}(X)=\left\{\begin{aligned}
0, & X<\alpha_{1} \\
\frac{X-\alpha_{1}}{\alpha_{2}-\alpha_{1}}, & \alpha_{1} \leq X \leq \alpha_{2} \\
\frac{\alpha_{3}-X}{\alpha_{3}-\alpha_{2}}, & \alpha_{2} \leq X \leq \alpha_{3} \\
0, & X>\alpha_{3}
\end{aligned}\right.
$$




\section{2. Çalışma Alanı ve Materyal (Work Area and Material)}

Bu araştırma çalışmasında, taşınmaz değerlemede bulanık mantık modellemesinin uygulanabilirliği ve hazırlanan veri setindeki değişkenlerin azaltılmasının yöntem üzerine etkileri araștırılmıştır. Araştırma sahası olarak İzmir ili sınırları içerisinde bulunan Karşıyaka ilçesi, Konak ilçesi, Karabağlar ilçesi, Çiğli ilçesi, Bornova ilçesi, Bayraklı ilçesi, Menemen ilçesi, Aliağa ilçesi, Balçova ilçesi, Buca ilçesi, Güzelbahçe ilçesi, Kemalpaşa ilçesi, Bergama ilçesi, Ödemiş ilçesi, Narlıdere ilçesi, Gaziemir ilçesi ve Dikili ilçesinde (Şekil 4) yaklaşık 120 yapıdan alınan bağımsız bölümlerine ait değerleme raporları kullanılmıştır. Verilerin elde edilmesi için Code Gayrimenkul Değerleme Dan. İnş. Taah. San. Tic. Ltd. Şti. ile birlikte çalışılmıştır.

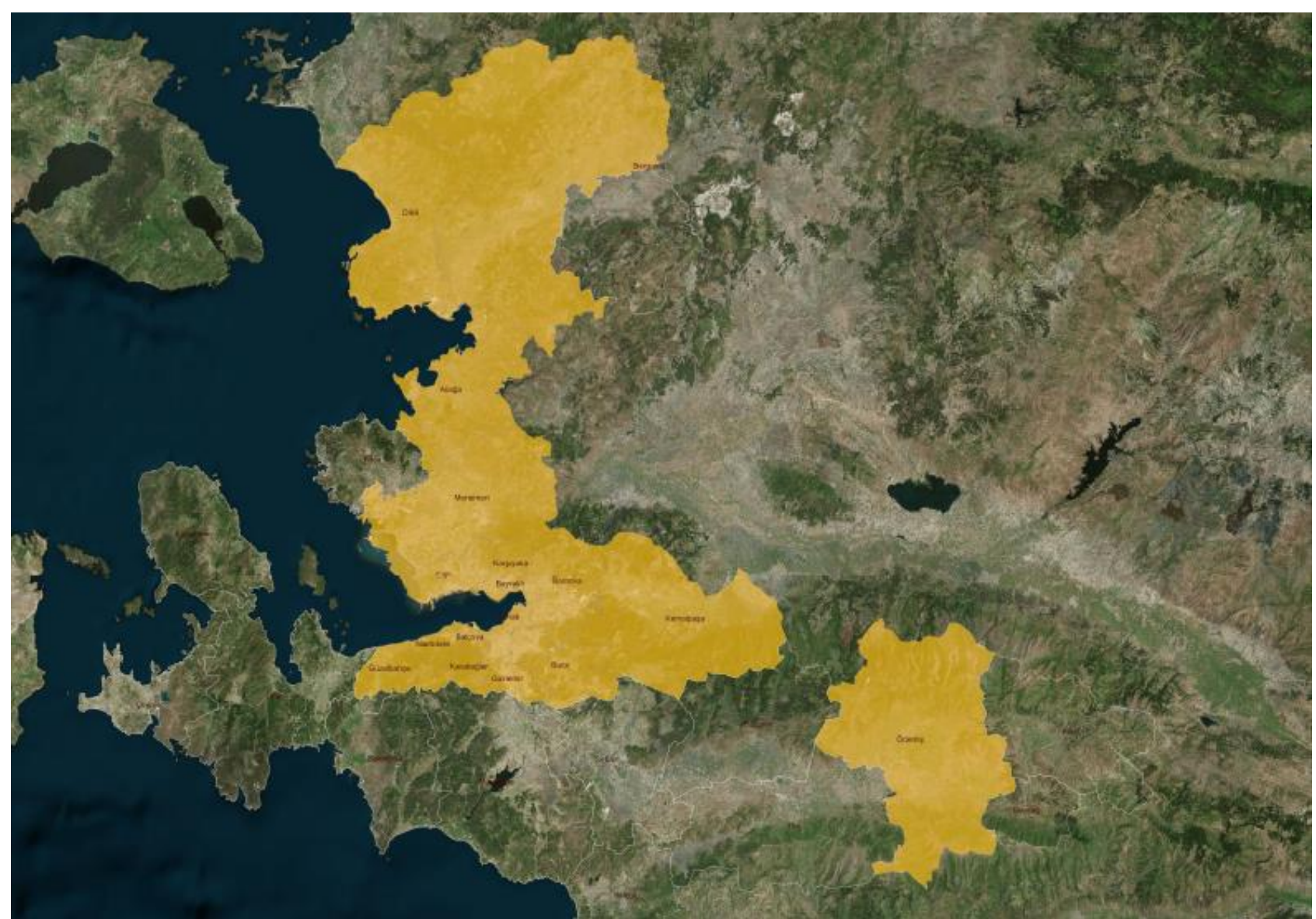

Şekil 4. Çalışmada yer alan bağımsız bölümlerin bulunduğu ilçeleri gösteren harita (Map of the districts where the independent units in the study are located)

Toplanan verilerden 9 adet bağımsız değişken (Ulaşım, daire alanı, cephe durumu, otopark durumu, binanın yaşı, asansör, manzara, gelir seviyesi ve yapı kalitesi) ve 1 adet bağımlı değișken (bağımsız bölümün satıș değeri) olarak veri seti hazırlanmıştır. Hazırlanan bu veri setinin \%75' i eğitim verisi ve \% 25' i ise test verisi olarak sisteme tanıtılmıştır (Canaz Sevgen ve Aliefendioğlu Tanrıvermiş, 2020; Esen, 2014; Yücel, 2010). Bağımsız değişkenlerden yapı kalitesi, binada kullanılan malzemeyi, geçirmiş olduğu tadilatı, işlevini yani kısaca değerlemeyi yapan kişinin yorumunu katarak bağımsız bölümün genel yapısını içermektedir. Yapı kalitesine ilişkin sınıflama değerleme uzmanlarınca oluşturulan değerleme raporlarından alınmıştır. Ulaşım değişkeninde ise şehir merkezine ulașımın Otobüs, Minibüs, Metro, İzban (kent içi raylı toplu taşıma sistemi) ve vapur olanaklarından hangisinin kullanıldığına bakılmaktadır. Taşınmazların bir bölgeden değil de heterojen olarak seçilmesi değişken sayısını artıracaktır. Bu çalışmada 9 değişkenden daha fazla değişken belirlenebilirdi fakat amaç, zaman ve ekonomik açıdan kazanım sağlanması bürokratik işlemlerin en aza indirilmesi göz önünde bulundurulduğunda, ortak değişkenlerin kullanılması tercih edilmiştir (Esen 2014).

\section{Deneysel Sonuçlar (Experimental Results)}

Taşınmaz değerlemede veri seti 9 adet bağımsız ve 1 adet bağımlı değişken olarak hazırlanmıştır. Ulaşım, daire alanı, cephe durumu, otopark durumu, binanın yaşı, asansör, manzara, gelir seviyesi ve yapı kalitesi gibi özellikler 
bağımsız, değer de bağımlı değişken verisi olarak kullanılmış ve çoklu regresyon uygulanmıştır. Kurulan regresyon modeli, istatistiksel açıdan bağımsız değişkenlerin bağımlı değişkendeki varyansını ( ${ }^{2}$ ) \% 75 olarak (Tablo 1) açıklamaktadır. Emlak piyasası koşullarında \% 85 ve üzerindeki tahmin değerleri kabul edilebilir sınırlar içerisinde değerlendirilmektedir (Saraç, 2012). Regresyon analizi sonucunda ulaşılan tahmin değerinin (\%75), belirtilen eșik değerin altında kalması nedeniyle değișken sayısı azaltılarak yeni modeller test edilmeye devam edilmiştir. Daha etkin bir model oluşturmak için veri setinde nitelik azaltmaya karar verilmiştir.

Tablo 1. Model özeti (Model summary)

\begin{tabular}{lllll}
\hline Model & $\mathrm{R}$ & $\mathrm{R}^{2}$ & $\begin{array}{l}\text { Düzeltilmiş } \\
\text { (Adjusted) } \mathrm{R}^{2}\end{array}$ & $\begin{array}{l}\text { Tahmin } \\
\text { standart hatası } \\
\text { (Std. Error of } \\
\text { the estimate) }\end{array}$ \\
\hline 1 & 0,867 & 0,752 & 0,732 & 26,26413 \\
\hline
\end{tabular}

Bu sebeple modele ( 9 değişken) stepwise regresyonu uygulanmıștır. Stepwise regresyon analizine dahil edilen 9 değişkenden 3' ünün taşınmazın satış değerini anlamlı olarak belirlediği görülmüştür. Bu anlamlı değișkenlerin 'yapı kalitesi', 'binanın yaşı' ve 'daire alanı' olduğu aşağıda Tablo 2' deki model analizinde görülmektedir.

Tablo 2. Kabul edilen değişkenler (Variables entered)

\begin{tabular}{lll}
\hline Model & $\begin{array}{l}\text { Kabul edilen değişkenler } \\
\text { (Variables entered) }\end{array}$ & Method \\
\hline 1 & Yapı kalitesi & Stepwise \\
2 & Daire alanı & Stepwise \\
3 & Binanın yaşı & Stepwise \\
\hline
\end{tabular}

Buradan hareketle çalışma başlangıcındaki modele bulanık mantık modellemesindeki nitelik azaltma basamağı da uygulanmiştır. Uygulamada 9'un 1'li kombinasyonu sonucu toplam 9 adet model oluşmuştur. Modeller incelendiğinde 'Yapı Kalitesi' nin çıktıyı en çok etkileyen değișken, diğer bir ifadeyle en düșük hata değerine sahip olduğu görülmüştür. 9'un 2'lisi sonucu toplam 36 adet model oluşmuş ve çıktıyı en çok etkileyen değişkenler 'Daire Alanı ve 'Yapı Kalitesi', 9'un 3'lü kombinasyonu sonucu toplam 84 adet model oluşmuş ve çıtıyı en çok etkileyen değişkeneler 'Daire Alanı', 'Yapı Yaşı' ve 'Yapı Kalitesi' olarak karşımıza çıkmıștır. Bu modelleme ile de elde edilen bağımsız değişkenlerle, stepwise regresyon modelinden elde edilen değişkenlerin aynı olduğu yani; 'Yapı kalitesi', 'Binanın yaşı' ve 'Daire alanı' olduğu Şekil 5' te de görülmektedir. Her iki modelde de aynı en az değişkenlerin elde edilmesi göz önünde bulundurularak, bu değişkenlere taşınmaz değerinin hesaplanması için yeniden bulanık mantık modellemesi ve sonuçların karşılaştırılması için çoklu regresyon modeli uygulanmıştır. 


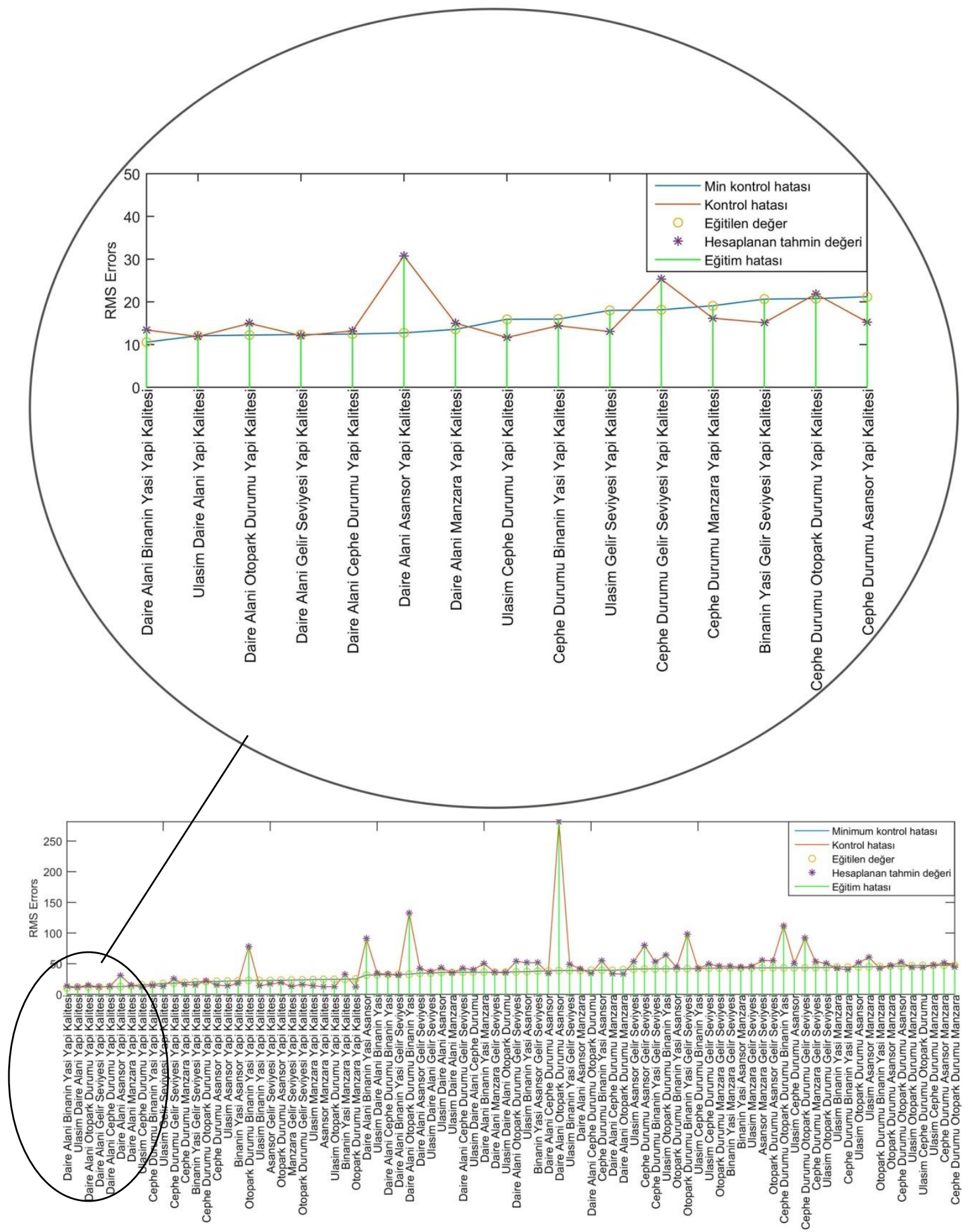

Şekil 5. Nitelik azaltma model sonucu (Results of quality reduction model)

Uygulanan bulanık mantık modellemesinde taşınmaz değerinin sabit kaldığı ve bu değerin belirlenmesinde eğitilecek değișken sayısı toplam verinin \% 75 i, test edilecek değișken sayısı da toplam verinin \% 25 i olacak şekilde programa tanıtılmıştır. Modelde 3 girdi ve 1 çıktı veri seti oluşturulmuştur. Girdi değişkenleri 'Daire Alanı', 'Binanın Yaşı' ve 'Yapı Kalitesi' dir. Çıktı değişkeni olarak da değerleme raporlarından elde edilen ve satış değeri olarak kullanılan 'Değer' değişkeni kullanılmıștır. Bulanık mantık modelinin eğitimi için elde edilen toplam verinin \% 75 'i kullanılırken, her bir değişkenin 'Değer' i belirlemesi için toplam verinin \% 25' i test aşaması için kullanılmıștır. Bu modelde her bir üyelik fonksiyonu tipi ve modeli tek tek denenmiş ve eğitim datası 20 çevrim eğitilmiştir. Eğitim tamamlandıktan sonra her bir değişken için 2 adet 'Trimf $f$ üyelik fonksiyonu ve melez öğrenme algoritması kullanılmıștır. Elde edilen veri setinden tahmin değerlerinin listelenmesi için de "Evalfis" komutu kullanılmıştır. 
Daire alanı, binanın yaşı ve yapı kalitesi modellerinde giriş parametreleri için tek tek üyelik fonksiyonlarının şekilleri tanımlanmıștır. Şekil 6' da Daire alanı için oluşturulan giriş üyelik fonksiyonu model grafiği görülmektedir.

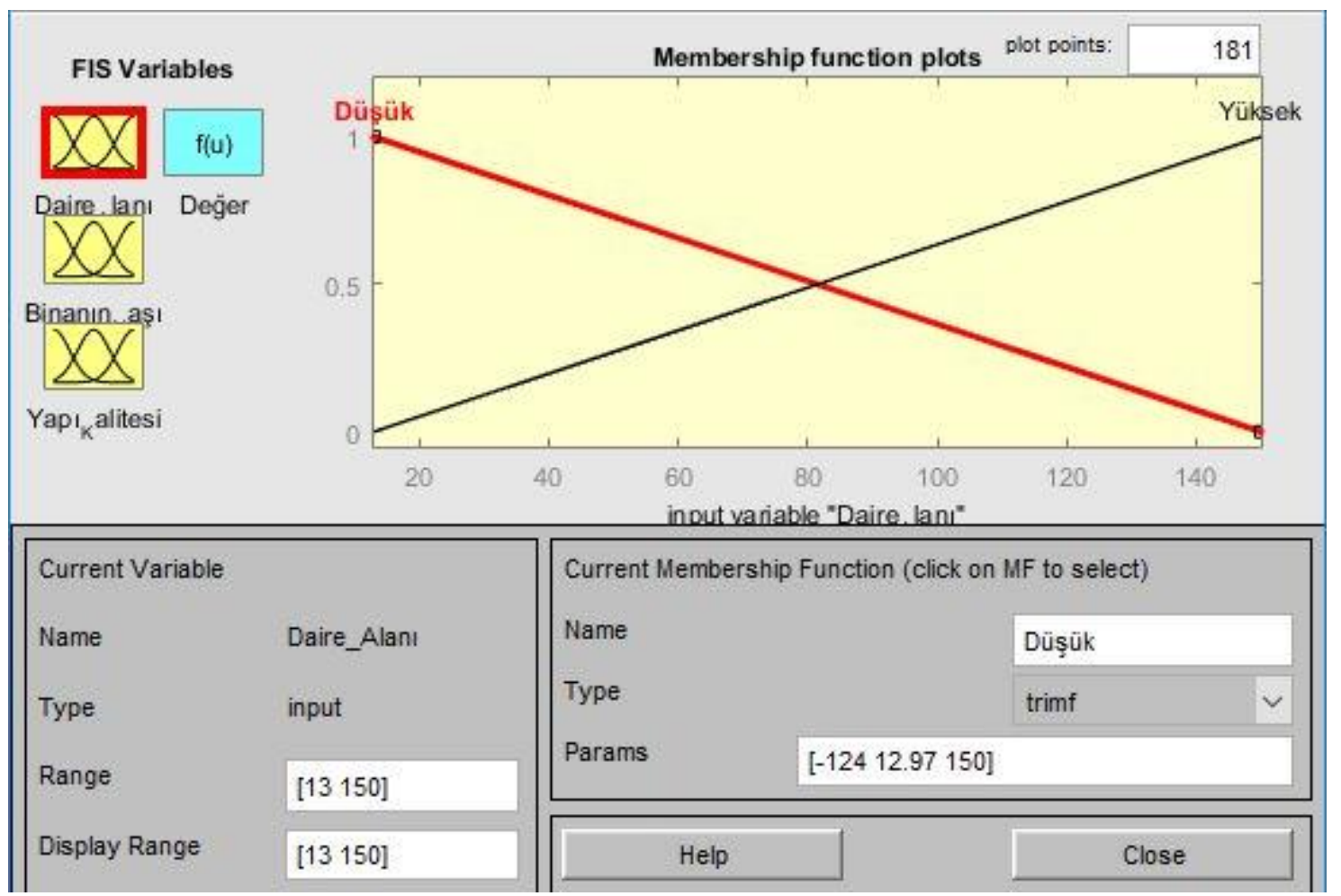

Şekil 6. Daire alanı için giriş üyelik fonksiyonu model grafiği (Input membership function pattern plot for flat area)

Kurulan model 8 kural içermektedir ve bu da 8 adet çıktı tipi oluşturmaktadır. Her bir çıktı kuralı için çok düşük, düşük, orta düşük, orta, orta yüksek, yüksek düşük, yüksek ve çok yüksek sözel değerleri Şekil 6' daki gibi sırayla tanımlanmıştır. Bütün bu sözel değer tanımlamaları sonucunda oluşan kural yapısı Şekil 7' deki gibi anlamlı hale gelmiştir. Örneğin ilk kuralın anlamı "Eğer 'Daire Alanı' düşük ve 'Binanın Yaşı' düşük 'Yapı Kalitesi' düşük ise 'Değer' çok düşüktür.” anlamına gelmektedir. Sonuç olarak ilgili kural görünümü modelin çıktılarının sözel değerler kullanılarak bulanık eğer-ise kuralları ile sunulmasını sağlamıștır.

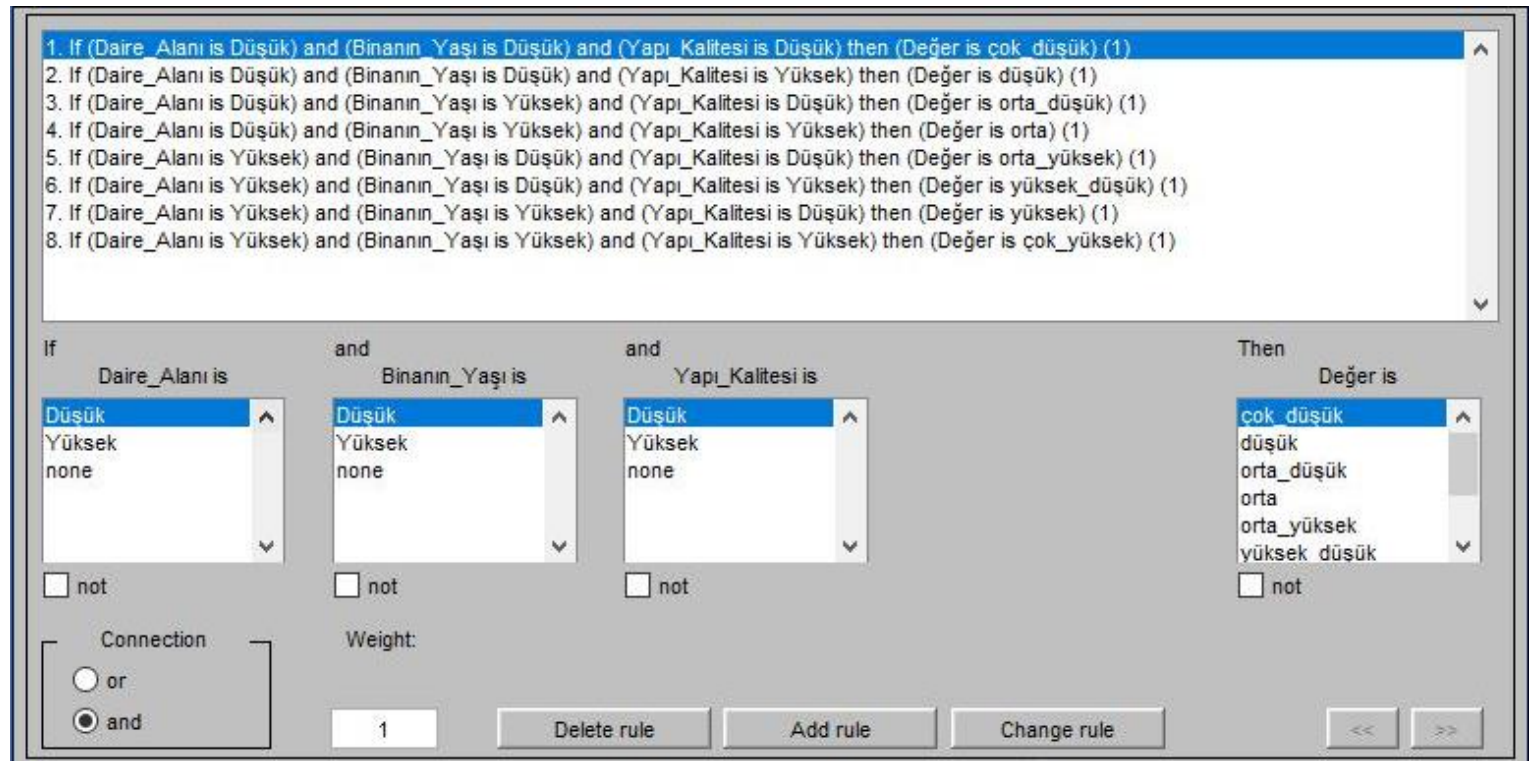

Şekil 7. Bulanık mantık modellemesinde kural görünümü (View of rules in fuzzy logic modeling)

Taşınmaz değer tahmini elde etmemize yardımcı olacak B değeri Tablo 3'te verilmiştir. B katsayısı ile 'Daire alanı', 'Binanın yaşı' ve 'Yapı kalitesi' nin değerlerini Eş.1' deki formülde yerine koyduğumuzda yaklaşık taşınmaz değeri sonucuna ulaşılmıştır. Buradan elde ettiğimiz yaklaşık taşınmaz değeri ile taşınmazın gerçek değeri arasındaki ortalama mutlak yüzde hata (MAPE) ve karekök ortalama hata (RMSE) kriterleri de hesaplanarak Tablo 4' te 
verilmiștir.

Tablo 3. Coklu regresyon özeti (Model summary)

\begin{tabular}{llll}
\hline Model & B & Standart Hata & Beta \\
\hline Sabit & 27,878 & 15,460 & \\
Daire Alanı & 0,582 & 0,128 & 0,251 \\
Binanın Yaşı & 0,647 & 0,307 & 0,109 \\
Yapı Kalitesi & 27,385 & 2,041 & 0,719 \\
\hline
\end{tabular}

Çoklu regresyon modeli ile bulanık mantık modelinden elde edilen test sonuçlarının karşılaștırılmasında ise; MAPE ve RMSE kriterleri kullanılmıștır. Bulanık mantık modelinde MAPE değeri 0,072 bulunmaktadır. Bu değer 1,0 değerine (1-0,072) \%93’ lük doğruluk ile yakınken, çoklu regresyon modelinde 0,133 (1-0,133) \%86’ lık doğruluk ile yakınlık göstermektedir. Aynı zamanda da RMSE değerlerinde de bulanık mantık modeli diğer modele göre daha iyi performans göstermiş ve daha düşük değerlere ulaşmıştır. Analiz sonuçlarına bakıldığında amaç en az değişken kullanarak en yakın tahmin değerini elde etmek olduğundan, taşınmaz değerleme veri setinde yapı kalitesi, daire alanı ve binanın yaşının kullanılabilir olduğu, bu değişkenler arasında bir uyumun olduğu ve bu modelden oldukça iyi tahminler elde edilebileceği, dolayısı ile geliştirilen bu modelin yararlı ve güçlü bir model olduğu görülmüştür.

Tablo 4.Taşınmaz tahmin değeri elde etmede kullanılan modellerin hata karşılaştırması (Errorcomparison of models used to obtain the reale state value estimation)

\begin{tabular}{lll}
\hline Model & RMSE & MAPE \\
\hline Matlab & 12,36 & 0,072 \\
SPSS & 23,63 & 0,133 \\
\hline
\end{tabular}

\section{Sonuç (Result)}

Taşınmaz değerlemesinde değişken tespiti en önemli konuların başında gelmektedir. Taşınmaz değerini etkileyen değişkenler ülkeden ülkeye, bölgeden bölgeye ve kişiden kişiye değişmektedir. Objektif ve doğru sonuçlar elde etmek için değişkenlerin doğru belirlenip modelleme yapılması, hem zaman hem iş gücü hem de ekonomik kayıpların önüne geçecektir.

Taşınmaz değerlemede kullanılan değişkenler kamu sektöründen alınmaktadır. Bu kurumlardaki değişken girişleri; kurumun direk değişkeni üretmesi veya ikinci bir kurumdan alması ya da vatandaşın kuruma beyanıyla olmaktadır. Haliyle bu değişkenlerde hatalar olabilmektedir. Ayrıca bazı değişkenlerin hiç bulunmamasının yanında; mevcut değișkenlerin eksikliği, düzensizliği ve içeriklerinin teknik bakımdan standart olmayıșı önemli ve büyük bir sorundur. Bundan dolayı bu bilgileri kullanılabilecek hale getirmek zaman ve emek gerektirmektedir. Anlaşılacağı üzere değerlemede en önemli problemlerden biri değere etki eden değişkenlerin net olmaması, diğeri klasik değerleme yöntemlerinin yetersiz kalması nedeniyle yöntem arayışının devam etmesidir. Teknolojinin gelişmesiyle değişkenlerin kendi başına ve aralarındaki ilişkilere göre ağırlıklı etkilerinin hesaplanabilmesi gibi olanaklar yeni yöntem arayışlarını devam ettirmektedir.

$\mathrm{Bu}$ çalışmada ise, taşınmaz değeri tespit edilmesinde gerekli değişkenler toplanırken yaşanan bürokratik işlemlerin zaman ve ekonomik açıdan kazanım sağlanması için bir model geliştirilmiştir. Model geliştirilirken karşılaşılan sorunların en başında elde edilen çok sayıda değişkenden, hangisinin veya hangilerinin dikkate alınması gerektiği gelmektedir. Yine bu çalışmamızda ulaşım, daire alanı, cephe durumu, otopark durumu, binanın yaşı, asansör, manzara, gelir seviyesi ve yapı kalitesi değişken olarak oluşturulmuştur. Bu değișkenleri aza indirebilmek için nitelik azaltma modeli kullanılmıştır. Geliştirilen bu modelde değişkenlerin en aza indirilerek gerçek değere en yakın tahmin değerine ulaşmak amaçlanmıştır. Bu bakımdan elde edilen veri setine uygulanan nitelik azaltma işlemi sonucunda değişkenler en aza indirilmiştir. Daha sonra bu değişkenlere bulanık mantık modeli tekrar uygulanmıştır. Bulanık mantık modeli ile elde edilen sonuçlar çoklu regresyon analizi ile karşılaştırılmıştır. Analiz sonuçlarına bakıldığında taşınmaz değerlemesinde en az değişken kullanılan bulanık mantık modelinin, gerçek değere en yakın tahmin değerlerini verdiği görülmüştür. Böylece bulanık mantık modeli ile en az değişken kullanılarak taşınmaz değerlemenin uygulanabilirliği ortaya konulmuştur.

\section{Teşekkür (Acknowledgement)}

Gazi Üniversitesi Fen Bilimleri Enstitüsü’ nde Dr. Öğretim Üyesi Hanifi TOKGÖZ’ ün danışmanlığında Yeşim Esen tarafından yürütülen" "Kamulaştırma bedel tespitinde uygulanan kriterlerin irdelenmesi -İzmir örneği" bașlıklı doktora tezinden üretilmiștir. 


\section{Çıkar Çatışması (Conflict of Interest)}

Yazarlar tarafından herhangi bir çıkar çatışması beyan edilmemiştir. No conflict of interest was declared by the authors.

\section{Kaynaklar (References)}

Anand, M. S.,Tyagi, B., 2012. Design and Implementation of Fuzzy Controller on FPGA, International Journal of Intelligent Systems and Applications, 4(10): 35-42.

Borst, R.A., 1991. Artificial Neural Networks: The Next Modelling/Calibration Technology For The Assessment Community, Property Tax Journal, 10(1), 69-94.

Bostancı, B., Bakır, Y. N., Doğan, U., Güngör, K. M., 2017. Research on GIS-Aided Housing Satisfaction Using Fuzzy DecisionMaking Techniques", Journal of the Faculty of Engineering and Architecture of Gazi University, 32(4): 1193-1207.

Budzyński, T.,and Wilkowski, W., 2006. Application of Artificial Neural Networks for Real Estate Valuation", 23 FIG Cangress, Munich, Germany, 8-13 October.

Canaz Sevgen, S., ve Aliefendioğlu Tanrıvermiș, Y., 2020. Mass Apprasial With A Machine Learning Algorithm: Random Forest Regression, Bilişim Teknolojileri Dergisi, 13(3), 301-311.

Cechin, A., Souto, A., and González, M. A., 2000. Real Estatevalue at Porto Alegre City Using Artificial Neural networks, Unisinos University, Brazil, 237-242.

Çakır, P. ve Sesli, F. A., 2013. Arsa Vasıflı Taşınmazların Değerine Etki Eden Faktörlerin ve Bu Faktörlerin Önem Sıralarının Belirlenmesi", Harita Teknolojileri Elektronik Dergisi, 5(3): 1-16.

Demirel, B., Yelek, A., Alağaș, H. M., Eren, T., 2018. Taşınmaz Değerleme Kriterlerinin Belirlenmesi ve Kriterlerin Önem Derecelerinin Çok Ölçütlü Karar Verme Yöntemi ile Hesaplanması", Kırıkkale University Journal of Social Sciences, 8(2): 665682.

Derinpınar, M. A., ve Aydınoğlu, A. C.. 2015. Bulanık Mantık ile Coğrafi Bilgi Teknolojilerini Kullanarak Taşınmaz Değerlemesi, 15. Türkiye Harita Bilimsel ve Teknik Kurultayı, Ankara.

Dikmen, S. U., Saraç, E., 2012. Estimation of the Selling Price of Apartment Units Using Artificial Neural Networks", Third International Conference on Construction in Developing Countries, Bangkok, Thailand.

Elmas, Ç., 2011. Yapay Zeka Uygulamaları, 2, Seçkin Yayıncllık, Ankara.

Erdem, N., 2017. Türkiye'de Taşınmaz Değerleme Alanında Yapılan Lisansüstü Tezlerinin İçerik Analizi", Akademik Platform Mühendislik ve Fen Bilimleri Dergisi, 6(1): 112-126.

Eren, E.,Tüdeş, T. ve Yomralığlu, T., 1999. Coğrafi Bilgi Sistemlerinde Raster Tekniği İle Kent Taşınmaz Değer Haritalarının Üretilmesi, Yerel Yönetimlerde Kent Bilgi Sistemi Uygulamaları Sempozyumu, Trabzon, 231-239.

Es, H. A., Kalender, F. Y. Ve Hamzaçebi, C., 2014. Forecasting the net Energy Demand of Turkey by Artifical Neural Networks", Journal of theFaculty of Engineering and Architecture of Gazi University, 26(3): 495-504.

Esen, Y., 2014. Kamulaștırma Bedel Tespitinde Uygulanan Kriterlerin İrdelenmesi -İzmir Örneği, Doktora Tezi, Gazi Üniversitesi Fen Bilimleri Enstitüsü.

Esperanza, M.,and Gallego, J., 2004. Artificial Intelligence Applied to Real Estate Valuation an Example for the Appraisal of Madrid", Catastro, 255-265.

García, N., Gámez, M., and Alfaro, E., 2008. ANN+GIS: An Automated System for Property Valuation", Science Direct Neuro computing, 71: 733-742

Güner, N. Ve Çomak, E., 2014. Lise Öğrencilerinin Matematik Dersine Yönelik Tutumlarının Bulanık Mantık Yöntemi ile İncelenmesi, Pamukkale Üniversitesi Mühendislik Bilimleri Dergisi, 20(5): 189-196.

Hong, J., Choi, H., Kim, W., 2020. A House Price Valuation Based On The Random Forest Approach: The Mass Appraisal Of Residential Property In South Korea, International Journal of Strategic Property Management, 24(3), 140-152.

Işıklı, M., 2019. Coğrafi Bilgi Sistemleri ile Taşınmaz Değerlemesi”, Yapı Bilgi Modelleme, 1(1): 27-32.

Jang, J. S. R., Sun, C.T. and Mizutani, E., 1996. Neuro-Fuzzy and Soft Computing: A Computational Approach to Learning and Machine Intelligence", PrenticeHall, A. B. D.

Kayaalp, G. T., Çelik Güney, M. Ve Cebeci, Z., 2015. Çoklu Doğrusal Regresyon Modelinde Değişken Seçiminin Zootekniye Uygulanışı", Çukurova Üniversitesi Ziraat Fakültesi Dergisi, 30 (1): 1 - 8.

Khalafallah, A., 2008. Neural Network Based Model For Predicting Housing market Performance, Tsinghua Science and Technology, 13: 325-328.

Kim, G. H., An, S. H., and Kang, K. I., 2004. Comparison of Construction Costestimating Models Based on Regression Analysis, Neural Networks, and Case-Based Reasoning", Building and Environment, 39:1235-1242.

Koçak, C.., Yiğit, T., 2020. Teknoloji Bağımlılığının Bulanık Mantık ile Sınıflandırılması, Mühendislik Bilimleri ve Tasarım Dergisi, 8(5): $126-132$.

Köktürk, E., 2009. Taşınmaz Değerleme: Durum Saptaması ve Yönelimler, Türkiye Mühendis ve Mimar Odaları Birliği Harita ve Kadastro Mühendisleri Odası 12. Türkiye Harita Bilimsel ve Teknik Kurultayl, Ankara

Kuzugüdenli, E., 2018. Bulanık Mantık Yöntemiyle Kızılçamda Verimliliğin Modellenmesi, Mühendislik Bilimleri ve Tasarım Dergisi, 6(3): $426-434$.

Nas Bulut, B., 2011. YSA ve DVM Yöntemleri ile Taşınmaz Değerlemesi İçin Bir Yaklașım Geliștirme”, Yüksek Lisans Tezi, Selçuk Üniversitesi Fen Bilimleri Enstitüsü.

Nişancı, R., 2005. Coğrafi Bilgi Sistemleri İle Nominal Değerleme Yöntemine Dayalı Piksel Tabanlı Kentsel Taşınmaz Değer Haritalarının Üretilmesi, Doktora Tezi, Karadeniz Teknik Üniversitesi, Fen Bilimleri Enstitüsü.

Özgür, B., Kara, R., 2020. Hastane Pnömatik Sistemlerinin Bulanık Mantıkla Modellenmesi, Mühendislik Bilimleri ve Tasarım Dergisi, 8(5): 25 - 34 . 
Özkan, G., Yalpır, Ş., and Uygunol, O., 2007. An Investigation on the Price estimation of Residable Real Estates by Using Artificial Neural Network and Regression Methods", XIIth Applied Stochastic Models and Data Analysis International Conference (ASMDA).

Rossini, P., 1997. Application of Artificial Neural Networks to The Valuation of Residential Property, 3. Annual Pacific-Rim Real Estate Society Conference, Palmerston North, New Zealand.

Saraç, E., 2012. "Yapay Sinir Ağları Metodu ile gayrimenkul Değerleme”, Yüksek Lisans Tezi, İstanbul Kültür Üniversitesi Fen Bilimleri Enstitüsü, İstanbul.

Şen, Z., 2009. Bulanık Mantık İlkeleri ve Modelleme", Genişletilmiş 3. Baskı, Su Vakfı Yayınları.

Tabar, M. E., ve Şişman, Y., 2020. Bulanık Mantık ile Arsa Değerleme Modelinin Olușturulması. Türkiye Arazi Yönetimi Dergisi, 2(1), 18-24.

Worzala, E.,Lenk, M., and Silva, A., 1995. An Exploration of Neural Networks And It Sapplication to Real Estate Valuation", The Journal of Real Estate Research, 10(2): 185-201.

Yalpır, Ș., 2007. Bulanık Mantık Metodolojisi İle Taşınmaz Değerleme Modelinin Geliștirilmesi ve Uygulaması: Konya Örneği, Doktora Tezi, Selçuk Üniversitesi Fen Bilimleri Enstitüsü.

Yalpır, Ș., Bünyan Ünel, F., 2016. Türkiye 'de ve Uluslararası Çalışmalarda Arsa Değerlemede Kullanılan Kriterlerin İrdelenmesi ve Faktör Analizi ile Azaltımı, Afyon Kocatepe Üniversitesi Fen ve Mühendislik Bilimleri Dergisi, 6, 303 - 322.

Yomralıoğlu, T., Nișancı, R., Çete, M., Candaș, E., 2011. Dünya'da ve Türkiye'de Tașınmaz Değerlemesi, Türkiye'de Sürdürülebilir Arazi Yönetimi Çalıştayı, Okan Üniversitesi.

Yücel, A., 2010. Tedarikçi Seçimi Probleminde Bütünleşik Sinirsel Bulanık Mantık Yaklaşımı, Doktora Tezi, Yıldız Teknik Üniversitesi Fen Bilimleri Enstitüsü, İstanbul.

Zurada, J. M.,Levitan, A. S., and Guan, J., 2006. Non-Conventional Approaches to Property Value Assessment", Journa of Applied Business Research, 22(3): 1-14. 